\title{
PELAKSANAAN FUNGSI REKOMENDASI OMBUDSMAN REPUBLIK INDONESIA KEPADA KEPALA DAERAH
}

\author{
Adam Setiawan \\ Fakultas Hukum, Universitas 17 Agustus 1945, Samarinda \\ email: adamsetiawanmunif@gmail.com
}

disampaikan 30/12/19 - di-review 14/6/2020 - diterima 03/12/2020

DOI: $10.25123 /$ vej.3657

\begin{abstract}
The author grapples with the issue of how Heads of Regional government respond to Ombudsman's recommendations, suggesting correction of public service failures, and what are the legal repercussions if those regional government heads chose to disregard such recommendation. Relevant legal norms - identified from existing legal sources - shall be discussed. It is suggested that Heads of Regional Governments are under the legal obligation to heed the given recommendation and rectify the government error as proposed. In practice, recommendations can and have been on numerous times been ignored. Administrative sanctions, i.e. obligatory special re-training-education programs, in the case of failure to meet Ombudsman's recommendation, has been dismissed with impunity by both the Ministry of Home Affairs and the Heads of Regional/Local government, by reason of political or legal considerations.
\end{abstract}

Keywords:

Ombudsman of the Republic of Indonesia, recommendation, sanction, special re-training-education

\begin{abstract}
Abstrak
Penelitian ini menelaah tanggapan Kepala Daerah terhadap rekomendasi Ombudsman Republik Indonesia berkenaan dengan koreksi terhadap kegagalan dalam layanan publik, dan selanjutnya implikasi hukum bilamana rekomendasi tersebut diabaikan. Penelaahan dilakukan dengan menelurusi peraturan perundang-undangan maupun sumber-sumber hukum lainnya. Kajian mengungkap bahwa pemenuhan rekomendasi Ombudsman seharusnya dipandang sebagai kewajiban dari Kepala Daerah yang terkait. Dalam kenyataan, rekomendasi dapat dan sering diabaikan. Ancaman sanksi terhadap ketidakpatuhan dalam bentuk pembinaan khusus pada Kepala Daerah yang mengabaikan rekomendasi tidak punya efek. Apalagi rekomendasi penjatuhan sanksi tersebut dapat dikesampingkan dengan mudah, tanpa ada kekuatiran akan konsekuensi hukum, oleh Menteri Dalam Negeri maupun Kepala Daerah terkait dengan mengajukan ragam pertimbangan hukum dan politik.
\end{abstract}

Kata Kunci:

Ombudsman Republik Indonesia, Rekomendasi, Sanksi, Pembinaan Khusus

\section{Pendahuluan}

Bergulirnya era reformasi, berbagai perubahan dilakukan oleh pemerintah dalam rangka mewujudkan sistem yang lebih responsif baik itu dari sektor ekonomi, sosial, politik, dan hukum. Semua usaha yang dilakukan pemerintah dengan tujuan memberikan kesejahteraan kepada rakyat sebagaimana disebutkan 
dalam mukadimah alinea ke-4 (empat) yang ada pada Undang-Undang Dasar Negara Republik Indonesia 1945 (UUD NRI 1945) yang bunyinya "Kemudian dari pada itu untuk membentuk suatu Pemerintahan Negara Indonesia yang melindungi segenap bangsa Indonesia dan seluruh tumpah darah Indonesia dan untuk memajukan kesejahteraan umum..."

Berdasarkan tujuan negara yang disebutkan dalam mukadimah UUD NRI 1945 mempunyai konsekuensi bahwa Negara wajib terlibat dalam penyelenggaraan pelayanan publik. Salah satu masalah krusial yang dihadapi Indonesia saat ini adalah menguatnya gejala public distrust di tengah-tengah masyarakat, sebagai akibat kesalahan berbagai instrumen birokrasi rezim masa lalu. ${ }^{1}$ Seperti diketahui bahwa era sebelumnya tepatnya era Orde Baru, penyelenggaraan negara dan pemerintahan diwarnai dengan praktek Maladministrasi antara lain terjadinya korupsi, kolusi, dan nepotisme. ${ }^{2}$

Pasca runtuhnya rezim Orde Baru, keberadaan Pemerintah Daerah untuk melayani kebutuhan masyarakat semakin penting, demi merealisasikan isi otonominya sesuai dengan kebutuhan masyarakat khususnya yang berada di daerah. Untuk menyelenggarakan pemerintahan yang baik dan upaya meningkatkan pelayanan publik serta penegakan hukum (law enforcement), dibutuhkan keberadaan lembaga pengawas eksternal yang secara efektif mampu mengawasi tugas penyelenggaraan pelayanan publik. Maka dari itu momentum untuk membentuk sebuah lembaga independen yang tugas pokoknya mengawasi kinerja pelayanan publik baik di pusat maupun di daerah-daerah. Hal ini sesuai dengan amanat Ketetapan Majelis Permusyawaratan Rakyat Nomor VIII/MPR/2001 tentang Rekomendasi Arah Kebijakan Pemberantasan dan Pencegahan Korupsi, Kolusi, dan Nepotisme yang salah satunya memerintahkan dibentuknya Ombudsman dengan undang-undang. ${ }^{3}$

1 Abi Ma'ruf Radjab, Kekuatan Mengikat Putusan Ajudikasi Ombudsman dalam Proses Penyelesaian Sengketa Pelayanan Publik, Jurnal Veritas et Justitia, Nomor 2, Volume. 1, hlm 444-472, Desember 2015

2 Lihat Penjelasan Undang-Undang Republik Indonesia Nomor 37 Tahun 2008 Tentang Ombudsman Republik Indonesia, Lembaran Negara Republik Indonesia Tahun 2008 Nomor 139, Tambahan Lembaran Negara Republik Indonesia Nomor 4899.

3 Id. 
Ombudsman adalah lembaga negara yang mempunyai kewenangan mengawasi penyelenggaraan pelayanan publik baik yang diselenggarakan oleh penyelenggara negara dan pemerintahan termasuk yang diselenggarakan oleh Badan Usaha Milik Negara, Badan Usaha Milik Daerah, dan Badan Hukum Milik Negara serta badan swasta atau perseorangan yang diberi tugas menyelenggarakan pelayanan publik tertentu yang sebagian atau seluruh dananya bersumber dari anggaran pendapatan dan belanja negara dan/atau anggaran pendapatan dan belanja daerah. ${ }^{4}$

Dalam menjalankan fungsi dan tugas, Ombudsman mempunyai wewenang sebagai berikut: 5

a. meminta keterangan secara lisan dan/atau tertulis dari Pelapor, Terlapor, atau pihak lain yang terkait mengenai Laporan yang disampaikan kepada Ombudsman;

b. memeriksa keputusan, surat-menyurat, atau dokumen lain yang ada pada Pelapor ataupun Terlapor untuk mendapatkan kebenaran suatu Laporan;

c. meminta klarifikasi dan/atau salinan atau fotokopi dokumen yang diperlukan dari instansi mana pun untuk pemeriksaan Laporan dari instansi Terlapor;

d. melakukan pemanggilan terhadap Pelapor, Terlapor, dan pihak lain yang terkait dengan Laporan;

e. menyelesaikan laporan melalui mediasi dan konsiliasi atas permintaan para pihak;

f. membuat Rekomendasi mengenai penyelesaian Laporan, termasuk Rekomendasi untuk membayar ganti rugi dan/atau rehabilitasi kepada pihak yang dirugikan;

g. demi kepentingan umum mengumumkan hasil temuan, kesimpulan, dan Rekomendasi.

Salah satu kewenangan Ombudsman Republik Indonesia adalah memberikan rekomendasi. Pengertian (begrip) Rekomendasi adalah sebagai saran (suggestion), namun kadangkala dapat juga berarti nasihat. ${ }^{6}$ Secara leterlijk

4 Lihat Pasal 1 ayat (1) Undang-Undang Nomor 37 Tahun 2008 Tentang Ombudsman Republik Indonesia, Lembaran Negara Republik Indonesia Tahun 2008 Nomor 139, Tambahan Lembaran Negara Republik Indonesia Nomor 4899.

5 Lihat Pasal 8 ayat (1) Undang-Undang Nomor 37 Tahun 2008 Tentang Ombudsman Republik Indonesia, Lembaran Negara Republik Indonesia Tahun 2008 Nomor 139, Tambahan Lembaran Negara Republik Indonesia Nomor 4899.

6 Sunaryati Hartono et.al., Panduan Investigasi untuk Indonesia, The Asia Foundation Indonesia, Jakarta, 2003, hlm. 77. 
rekomendasi mempunyai pengertian sebagaimana disebut dalam Pasal 1 ayat (7) Undang-Undang Nomor 37 Tahun 2008 Tentang Ombudsman Republik Indonesia (selanjutnya ditulis UU Ombudsman), sebagai berikut:

"Rekomendasi adalah kesimpulan, pendapat, dan saran yang disusun berdasarkan hasil investigasi Ombudsman, kepada atasan Terlapor untuk dilaksanakan dan/atau ditindaklanjuti dalam rangka peningkatan mutu penyelenggaraan administrasi pemerintahan yang baik."

Melalui instrumen rekomendasi yang dimiliki oleh Ombudsman Republik Indonesia, besar ekspektasi kita terhadap Ombudsman Republik Indonesia dengan pendekatan persuasif mampu menyelesaikan persoalan maladministrasi pelayanan publik yang dilakukan oleh Penyelenggara Pelayanan Publik khususnya yang berada di daerah dengan tujuan mewujudkan efektivitas penyelenggaraan pelayanan publik. Namun justru pada praktiknya rekomendasi yang diberikan Ombudsman seringkali tidak dipatuhi dan tidak dilaksanakan oleh Kepala Daerah. Dalam berbagai kasus ketidakpatuhan Kepala Daerah terhadap rekomendasi yang dikeluarkan oleh Ombudsman, Kepala Daerah bisa diposisikan sebagai Terlapor atau Atasan Terlapor. Sebagai contoh kasus terkait rekomendasi Ombudsman yang tidak dilaksanakan sebagian dan tidak dilaksanakan seluruhnya oleh Kepala Daearah sebagai berikut:

Pertama, mengenai rekomendasi yang tidak dilaksanakan terjadi pada tahun 2011, permasalahan bermula saat Ombudsman melalui rekomendasinya ${ }^{7}$ menyatakan bahwa Walikota Bogor Diani Budiarto telah melakukan penyimpangan praktik administrasi, atau maladministrasi terkait dengan penerbitan Surat Keputusan yang isinya mencabut Izin Mendirikan Bangunan dari GKI Yasmin itu. Lalu mengikuti beberapa rekomendasi yang dikeluarkan Ombudsman kepada Gubernur Jawa Barat dan Walikota Bogor untuk melaksanakan rekomendasi dan rekomendasi terakhir ditujukan kepada Menteri

7 Ombudsman Republik Indonesia Rekomendasi Nomor: 0011/REK/0259.2010/BS15/VII/2011 Tanggal 08 Juli 2011 tentang Pencabutan Surat Keputusan Walikota Bogor Nomor 645.45-137 Tahun 2011 Tertanggal 11 Maret 2011 Tentang Pencabutan Keputusan Walikota Bogor Nomor: 645.8-372 Tahun 2006 Tentang Izin Mendirikan Bangunan (IMB) Atas Nama Gereja Kristen Indonesia (GKI) Yang Terletak di Jalan K.H Abdullah Bin Nuh Nomor 31 Taman Yasmin Kelurahan Curug Mekar, Kecamatan Bogor 
Dalam Negeri melakukan pengawasan dalam rangka pelaksanaan rekomendasi ini. ${ }^{8}$

Kedua, mengenai rekomendasi yang tak ditanggapi terjadi pada tahun 2015, tepatnya di Jakarta yang pada waktu Ketua Ombudsman masih dipimpin oleh Danang Girindrawardana, ada 2 (dua) rekomendasi yang tidak dilaksanakan oleh Pemerintah Provinsi melalui Gubernurnya waktu itu yaitu Gubernur Basuki Tjahaja Purnama karena tidak melaksanakan dua rekomendasi Ombudsman sejak tahun 2013. Kedua rekomendasi tersebut merupakan warisan kepemimpinan Gubernur sebelumnya yang seyogianya diselesaikan oleh Gubernur DKI Jakarta Basuki Tjahja Purnama. ${ }^{9}$

Berdasarkan contoh kasus di atas menunjukan Kepala Daerah tidak mematuhi dan tidak melaksanakan rekomendasi Ombudsman, padahal rekomendasi wajib untuk dilaksanakan sebagaimana disebutkan Pasal 38 ayat (1) UU Ombudsman, Pasal 36 ayat (2) Undang-Undang Nomor 25 Tahun 2009 Tentang Pelayanan Publik dan Pasal 351 ayat (4) Undang-Undang Nomor 23 Tahun 2014 Tentang Pemerintahan Daerah.

Selain itu timbul problematika lainnya terkait sanksi yang didapatkan oleh Kepala Daerah jika Rekomendasi yang diberikan oleh Ombudsman tidak dilaksanakan. Dalam hal ini Kepala Daerah diposisikan sebagai Terlapor dikarenakan tidak melaksanakan rekomendasi yang diberikan oleh Ombudsman Republik Indonesia. Seperti contoh yang disebutkan sebelumnya ketika Walikota Bogor dan Gubernur Jawa Barat tidak melaksanakan rekomendasi Ombudsman Republik Indonesia. Berdasarkan Pasal 351 ayat (4) Undang-Undang Nomor 23 Tahun 2014 tentang Pemerintah Daerah (selanjutnya disebut UU Pemda) disebutkan bahwa Kepala daerah wajib melaksanakan rekomendasi Ombudsman sebagai tindak lanjut pengaduan masyarakat sebagaimana dimaksud pada ayat (1). Hal tersebut tentunya mempunyai konsekuensi, karena rekomendasi bersifat

8 Detiknews, Ombudsman: Kasus GKI Yasmin Jadi Preseden Buruk Penegakan Hukum https://news.detik.com/berita/d-1791550/ombudsman-kasus-gki-yasmin-jadi-presedenburuk-penegakan-hukum, diakses 25 Juni 2020.

9 DetikNews, Ombudsman akan Tegur Ahok karena Tak Jalankan Rekomendasi https://news.detik.com/berita-jawa-barat/d-3330136/ombudsman-ri-keluhan-buruknyalayanan-pemda-paling-tinggi, diakses 1 April 2020. 
imperatif, sebagaimana disebutkan dalam Pasal 351 ayat (5) UU Pemda, Kepala daerah yang tidak melaksanakan rekomendasi Ombudsman sebagai tindak lanjut pengaduan masyarakat sebagaimana dimaksud pada ayat (4) diberikan sanksi berupa pembinaan khusus pendalaman bidang pemerintahan yang dilaksanakan oleh Kementerian serta tugas dan kewenangannya dilaksanakan oleh wakil kepala daerah atau pejabat yang ditunjuk.

Berdasarkan beberapa contoh rekomendasi Ombudsman yang telah dikemukakan di atas, terlihat jelas adanya kesenjangan hukum (legal gap), pertentangan antara das sein (kenyataan) dan das sollen (seharusnya) jika ditautkan dengan hukum positif. Menarik untuk diteliti lebih dalam (1) terkait pelaksanaan fungsi Rekomendasi Ombudsman kepada Kepala Daerah (2) bagaimana bentuk dan implementasi sanksi yang diberikan kepada Kepala Daerah dikarenakan tidak melaksanakan Rekomendasi Ombudsman Republik Indonesia?

Riset pada penulisan ini menggunakan penelitian hukum normatif atau penelitian hukum doktrinal. Pertama, dengan pendekatan undang-undang (statute approach). Pendekatan undang-undang dan regulasi yang bersangkutan yang bersangkut paut pada isu hukum yang sedang ditangani. ${ }^{10}$ Kedua, Pendekatan Konseptual (Concept Approach) Pendekatan konseptual beranjak dari pandanganpandangan dan doktrin-doktrin yang berkembang di dalam ilmu hukum. Dengan mempelajari pandangan-pandangan dan doktrin-doktrin ilmu hukum, peneliti akan menemukan ide-ide yang melahirkan pengertian-pengertian hukum, konsepkonsep hukum, dan asas-asas hukum yang relevan dengan isu yang dihadapi. Pemahaman akan pandangan-pandangan dan doktrin-doktrin tersebut merupakan sandaran bagi peneliti dalam membangunan suatu argumentasi hukum dalam memecahkan isu yang dihadapi. ${ }^{11}$

\footnotetext{
10 Amiruddin dan Zainal Asikin, Pengantar Metode Penelitian Hukum, Raja Grafindo, Jakarta, 2004, hlm. 131.

11 Id.
} 


\section{Pembahasan}

\section{Pelaksanaan Fungsi Rekomendasi Ombudsman Republik Indonesia Kepada}

Kepala Daerah

Pada praktiknya apabila terjadi tindakan, keputusan, atau peristiwa maladministrasi maka Penyelenggara Pelayanan Publik wajib untuk segera memperbaikinya atau memberikan ganti rugi (bila sudah ada ketentuan tentang ajudikasi khusus), baik melalui saran atau rekomendasi Ombudsman maupun atas inisiatif (ex officio) dari Pelaksana Pelayanan Publik itu sendiri. ${ }^{12}$ Sebagaimana disebutkan dalam Pasal 38 ayat (1) UU Ombudsman. Demikian pula diperuntukan terhadap Kepala Daerah untuk wajib melaksanakan rekomendasi yang dikeluarkan oleh Ombudsman Republik Indonesia sebagaimana Pasal 351 ayat (4) UU Pemda menyebutkan bahwa Kepala daerah wajib melaksanakan rekomendasi Ombudsman sebagai tindak lanjut pengaduan masyarakat sebagaimana dimaksud pada ayat (1).

Akan tetapi norma-norma tersebut bertolak belakang dengan realitas yang ada dimana Penyelenggara Pelayanan Publik termasuk Kepala Daerah yang notabene merupakan Pembina Pelayanan Publik, masih saja ada yang mengabaikan rekomendasi yang diberikan Ombudsman dengan berbagai alasan.

Laporan tahunan yang dirilis oleh Ombudsman bahwa jumlah rekomendasi yang pernah diterbitkan oleh Ombudsman, dalam kurun waktu tahun 2008 hingga 2018 tercatat sebanyak 33 (tiga puluh tiga) Rekomendasi yang dilaksanakan, 10 (sepuluh) rekomendasi dilaksanakan sebagian dengan alasan yang dapat diterima, 5 (lima) rekomendasi dilaksanakan sebagian dengan alasan yang tidak dapat diterima, 5 (lima) rekomendasi tidak dilaksanakan dengan alasan yang dapat diterima, 17 (tujuh belas) rekomendasi tidak dilaksanakan dengan alasan yang tidak dapat diterima, dan 17 (tujuh belas) rekomendasi dalam proses menentukan

12 Hendra Nurtjahjo et.al, Memahami Maladministrasi, Ombudsman Republik Indonesia, Jakarta, 2013, hlm., 8. 
status. Sehingga secara total, dalam kurun waktu tahun 2008 hingga 2018, Ombudsman telah menerbitkan 87 (delapan puluh tujuh) rekomendasi. ${ }^{13}$

Berdasarkan Pasal 1 ayat (7) UU Ombudsman, yang dimaksud dengan Rekomendasi yakni:

Rekomendasi adalah kesimpulan, pendapat, dan saran yang disusun berdasarkan hasil investigasi Ombudsman, kepada atasan Terlapor untuk dilaksanakan dan/atau ditindaklanjuti dalam rangka peningkatan mutu penyelenggaraan administrasi pemerintahan yang baik.

Pasal 36 Undang-Undang Nomor 37 Tahun 2008, rekomendasi Ombudsman dikeluarkan apabila:

a. Mediasi dan/atau konsiliasi gagal dilaksanakan;

b. Mediasi dan/atau tidak mencapai kesepakatan; atau

c. ditemukan bentuk maladministrasi

Setelah dikeluarkannya rekomendasi oleh Ombudsman terhadap Terlapor atau Atasan Terlapor. Untuk memastikan rekomendasi yang dikeluarkan telah dilaksanakan oleh Kepala Daerah, Ombudsman melalui Unit Resolusi dan Monitoring akan melakukan monitoring pelaksanaan rekomendasi sebagaimana disebutkan dalam Pasal 41 Peraturan Ombudsman Republik Indonesia Nomor 26 Tahun 2017 Tentang Tata Cara Penerimaan, Pemeriksaan, dan Penyelesaian Pelaporan.

Rekomendasi adalah lebih dari sekadar saran atau nasihat biasa kepada Pejabat Pemerintah atau Penyelenggara Negara tentang apa yang harus dilakukan guna memperbaiki pelayanan yang dikeluhkan masyarakat, baik itu yang sifatnya kasus perkasus maupun yang sifatnya sistemik. Oleh sebab itu rekomendasi dari Ombudsman berkaitan dengan tugasnya sebagai pengawas yang ditunjuk oleh Dewan Perwakilan Rakyat/Daerah untuk meningkatkan penyelenggaraan pemerintahan yang baik (good governance) serta menciptakan lingkungan yang kondusif untuk pelayanan (hukum yang adil, termasuk pemberantasan dan mencegah perilaku KKN). ${ }^{14}$ Dengan demikian fungsi rekomendasi Ombudsman

13 Lihat Laporan tahunan Ombudsman Republik Indonesia https://ombudsman.go.id/produk?c=19, diakses 2 Mei 2020.

14 Sunaryati Hartono, Supra No 6, hlm. 77 
yakni dalam rangka pengawasan (controlling) memperbaiki kualitas pelayanan publik dan meningkatkan efektivitas penyelenggaraan pelayanan publik.

Namun jika ditelaah secara cermat pada tahap pelaksanaan rekomendasi yang diberikan Ombudsman tidak berjalan sebagaimana mestinya fungsi rekomendasi. Hal demikian dapat dilihat dari laporan tahunan Ombudsman yang telah dikemukakan sebelumnya bahwa masih ada sebagian Kepala Daerah yang tidak melaksanakan sebagian maupun seluruh substansi rekomendasi Ombudsman.

Berdasarkan hasil wawancara yang dilakukan terhadap beberapa Asisten Ombudsman disimpulkan ada 4 (empat) faktor yang mempengaruhi Kepala Daerah tidak melaksanakan Rekomendasi yang diberikan oleh Ombudsman Republik Indonesia sebagai berikut: ${ }^{15}$ Pertama, ketidaktahuan Kepala Daerah terhadap fungsi rekomendasi Ombudsman dikarenakan kurangnya sosialisasi mengenai tugas dan fungsi Ombudsman sebagai lembaga pengawas pelayanan publik. Kedua, Kepala Daerah merasa tidak melakukan maladministrasi sebagaimana hasil pemeriksaan Ombudsman, atau Kepala Daerah merasa tidak melakukan semua unsur maladministrasi seperti yang didugakan kepada dirinya (sehingga rekomendasi hanya dilaksanakan sebagian). Ketiga, perbedaan interpretasi antara Ombudsman Republik Indonesia dan Kepala Daerah terhadap suatu peraturan yang diduga dilanggar oleh Kepala Daerah. Keempat, Kepala Daerah menganggap rekomendasi hanya sebagai saran biasa yang tidak mempunyai kekuatan hukum (non legally binding), sehingga pada akhirnya Kepala Daerah merasa wajib melaksanakan rekomendasi Ombudsman Republik Indonesia.

Padahal berdasarkan, Pasal 38 Undang-Undang Nomor 37 Tahun 2008 Tentang Ombudsman Republik Indonesia, Pasal 36 ayat (2) Undang-Undang Nomor 25 Tahun 2009 Tentang Pelayanan Publik dan dalam Pasal 351 ayat (4) Undang-Undang Nomor 23 Tahun 2014 Tentang Pemerintah Daerah, disebutkan

15 Hasil wawancara dengan Jaka Susila Wahyuana Asisten Ombudsman Perwakilan Daerah Istimewa Yogyakarta (12 Januari 2019), Tri Lindawati Asisten Ombudsman Perwakilan Jawa Tengah (30 Januari 2019), Muhammad Firhansyah Asisten Ombudsman Perwakilan Daerah Kalimantan Selatan (7 Februari 2019). 
secara expressis verbis atau eksplisit bahwa rekomendasi Ombudsman mempunyai kekuatan hukum mengikat (legally binding).

Jika menggunakan penafsiran gramatikal yang merupakan metode penafsiran atau penjelasan yang paling sederhana untuk mengetahui makna ketentuan undang-undang dengan menguraikannya menurut bahasa susun kata atau bunyinya. ${ }^{16}$ Dengan mengacu pada beberapa redaksi pasal yang disebutkan di atas telah menjelaskan bahwa frasa "wajib" mempunyai sifat imperatif, mengharuskan untuk melakukan sebagaimana diperintah oleh undang-undang.

Secara normatif, penjelasan makna wajib telah diatur dalam Lampiran II Nomor 268, Undang-Undang Nomor 12 Tahun 2011 Tentang Pembentukan Peraturan Perundang-Undangan dalam memberikan petunjuk teknik penyusunan peraturan perundang-undangan menerangkan penafsiran frasa "wajib" untuk menyatakan adanya suatu kewajiban yang telah ditetapkan, digunakan kata wajib. Apabila kewajiban tersebut tidak dipenuhi, yang bersangkutan dijatuhi sanksi. ${ }^{17}$

Merujuk redaksi pasal a quo, ada yang berpendapat bahwa rekomendasi Ombudsman telah memiliki kekuatan hukum yang wajib dilaksanakan oleh suatu instansi publik. Argumentasi tersebut diperkuat dengan kewenangan Ombudsman untuk mengeluarkan rekomendasi berlandaskan undang-undang yang di dalamnya ada kewenangan khusus yang diberikan oleh Dewan Perwakilan Rakyat dan Pemerintah karena itu rekomendasi Ombudsman masuk sebagai tatanan hukum yang diberlakukan di Indonesia. ${ }^{18}$ Setiap rekomendasi yang diberikan oleh Ombudsman Republik Indonesia sudah melalui tahapan dan rekomendasi Ombudsman wajib untuk dilaksanakan serta tidak dapat dilakukan banding atas

16 Sudikno Mertokusumo, Mengenal Hukum Suatu Pengantar, Liberty, Yogyakarta, 2008, hlm., 170.

17 Lihat Lampiran Undang-Undang Nomor 12 Tahun 2011 tentang Pembentukan Peraturan Peraturan Perundang-Undangan, Lembaran Negara Republik Indonesia Tahun 2011 Nomor 82, Tambahan Lembaran Negara Republik Indonesia Nomor 5234.

18 Nuryanto A. Daim Telaah Yuridis Kekuatan Hukum Rekomendasi Ombudsman, Ombudsman Republik Indonesia-Perwakilan Jawa Timur. Surabaya dikutip dari Muhamad Rus'anYasin, Telaah Tentang Rekomendasi Ombudsman Terhadap Fraud Perbankan, Jurnal Katalogis, Nomor 11, Volume. 4, hlm., 111-113, November 2016. 
keputusan yang sudah dikeluarkan tersebut. Rekomendasi mempunyai 3 (tiga) macam kekuatan, yaitu ${ }^{19}$ :

1) Kekuatan mengikat menurut hukum (legally binding).

2) Kekuatan mengikat secara moral (morally binding).

3) Kekuatan mengikat secara politik (politically binding).

Kekuatan rekomendasi Ombudsman tersebut dapat diuraikan sebagai berikut. Pertama, rekomendasi Ombudsman mengikat menurut hukum (legally binding), karena secara normatif sudah termuat dalam Undang-Undang baik dalam Pasal 38 Undang-Undang Nomor 37 Tahun 2008 Tentang Ombudsman Republik Indonesia Pasal 36 ayat (2) dan (3) Undang-Undang Nomor 25 Tahun 2009 Tentang Pelayanan Publik, maupun dalam Pasal 351 Undang-Undang Nomor 23 Tahun 2014, bahwa menjalankan Rekomendasi Ombudsman adalah wajib dilaksanakan oleh setiap terlapor dan atasan terlapor, dan kalau tidak melaksanakannya akan dikenakan sanksi administrasi sesuai dengan ketentuan peraturan perundang-undangan yang berlaku.

Kedua, rekomendasi Ombudsman mengikat secara moral (morally binding). Menurut Masdar F. Masudi, rekomendasi Ombudsman yang sifatnya morally binding pada dasarnya mencoba menempatkan manusia pada martabat mulia, sehingga untuk melakukan sesuatu atau tidak melakukan sesuatu, seorang pejabat publik tidak harus diancam dengan sanksi hukum, melainkan melalui kesadaran moral yang tumbuh dari lubuk hati paling dalam untuk melaksanakan perbaikan pelayanan publik. ${ }^{20}$

Ketiga, rekomendasi Ombudsman mengikat secara politik (politically binding). Dalam Pasal 38 ayat (4) Undang-Undang Nomor 37 Tahun 2008, disebutkan dalam hal terlapor dan atasan terlapor tidak melaksanakan rekomendasi atau hanya melaksanakan sebagian rekomendasi dengan alasan yang tidak dapat diterima oleh Ombudsman, Ombudsman dapat mempublikasikan

Id.

20 Masdar F. Mas'udi, Ombudsman melawan Positivisme Hukum demi Good Governance dan Keadilan, dalam C. F. G Sunaryati Hartono, ed., Peranan Ombudsman Dalam Rangka Pemberantasan Dan Pencegahan Korupsi Serta Penyelenggaraan Pemerintahan Yang Bersih, Jakarta, Komisi Ombudsman Nasional, 2005, hlm., 34. 
atasan terlapor yang tidak melaksanakan rekomendasi dan menyampaikan laporan kepada Dewan Perwakilan Rakyat dan Presiden. ${ }^{21}$ Namun pernyataan tersebut tidak mempunyai basis argumentasi yang kuat jika disandingkan dengan praktiknya bahwa masih ada Pelaksana Pelayanan Publik termasuk Kepala Daerah yang mengabaikan rekomendasi yang dikeluarkan oleh Ombudsman sehingga cenderung merugikan hak-hak Terlapor.

Mary A. Marshall dan Linda C.Reif dalam tulisannya mengatakan bahwa In general, the role of the Ombudsman is to make recommendations and to work through persuasion. He does not have power to force compliance with his recommendations but operates instead through discussion with the government. ${ }^{22}$

Milan Remac menjelaskan bagaimana cara kerja Ombudsman dalam menggunakan instrumen rekomendasi pada umumnya, The Ombudsman only have persuasive authority that results from the fact that the assessment standards are based on the experiences of the Ombudsman and on the status of particular Ombudsman in each and every legal system. Their persuasiveness is not backed up by any legally binding provisions. This leaves a great deal of scope for the administrative bodies and their discretion. They can decide whether the reports of the ombudsman and his recommendations are going to be complied with or not. If they do not comply with them, nothing really happens as noncompliance with this type of document does not entail any real legal sanction.

Adnan Buyung Nasution mengemukakan bahwa Ombudsman Republik Indonesia hanya mengharapkan kesadaran belaka dari instansi terkait yang diberikan teguran atau rekomendasi karena melakukan maladministrasi dan sebagainya. Berdasarkan kesadaran untuk mengambil tindakan dan melakukan koreksi serta perbaikan berdasarkan teguran atau rekomendasi karena melakukan maladministrasi. Berdasarkan kesadaran sendiri untuk mengambil tindakan dan melakukan koreksi serta perbaikan berdasarkan rekomendasi Ombudsman, tidak bisa sepenuhnya tepat guna dan tepat sasaran. Lebih lanjut,

21 Id.

22 Mary A. Marshall and Linda C.Reif, The Ombudsman: Maladministration and Alternative Dispute, Alberta Law Review, Volume XXXIV, Nomor I, hlm., 222-223, 1995. 
Adnan Buyung Nasution menegaskan bahwa Ombudsman hanya berupaya memberi dorongan terhadap institusi terkait agar terikat secara moral dilandasi oleh kesadarannya sendiri untuk tidak melakukan penyimpangan, untuk mengambil tindakan pengawasan (controlling action) serta melakukan perbaikan yang diperlukan. Tidak ada sanksi-sanksi yang diberlakukan. Wajar apabila banyak yang mengatakan bahwa dalam konteks Indonesia rekomendasi Ombudsman yang tidak mengikat dan tidak ada sanksi apapun merupakan kelemahan yang mendasar dari keberadaan Ombudsman. ${ }^{23}$

Berbeda halnya dengan keadaan di Denmark, dan New Zealand, saransaran atau rekomendasi Ombudsman sangat berwibawa dan karenanya sangat diperhatikan, bahkan jarang sekali dijumpai adanya saran atau rekomendasi seorang Ombudsman diabaikan oleh pemerintah. Selain disebabkan karena Ombudsman bekerja secara profesional dan obyektif, juga didukung oleh Parlemen, karena Ombudsman melaporkan segala, aktivitasnya kepada Parlemen, dan laporan Ombudsman kepada Parlemen dijadikan bahan oleh Parlemen untuk menilai kinerja Pemerintah. Sehingga apabila Pemerintah tidak memperhatikan rekomendasi Ombudsman, kemungkinan Pemerintah akan mendapatkan penilaian buruk oleh Parlemen. ${ }^{24}$.

Berdasarkan beberapa pendapat ahli dan realitas yang ada dapat disimpulkan bahwa sekalipun undang-undang telah mengatur secara eksplisit bahwa rekomendasi Ombudsman Republik Indonesia bersifat imperatif sebagaimana disebutkan dalam Pasal 38 ayat (1) dengan frasa Terlapor dan atasan Terlapor wajib melaksanakan Rekomendasi Ombudsman dan Pasal 351 ayat (4) Undang-Undang Nomor 23 Tahun 2014 Tentang Pemerintah Daerah, yang menyebutkan bahwa Kepala Daerah wajib melaksanakan Rekomendasi Ombudsman sebagai tindak lanjut pengaduan masyarakat sebagaimana dimaksud pada ayat (1). Namun bukan berarti jaminan bagi Kepala Daerah untuk melaksanakan rekomendasi yang dikeluarkan oleh Ombudsman Republik

23 Nina Pane, Adnan Buyung Nasution: Nasihat Untuk SBY, Kompas, Jakarta 2012, hlm., 209.

24 Galang Asmara, Peranan Ombudsman Dalam Mewujudkan Good Governance di Indonesia, Jurnal Perspektif, Volume VII, Nomor. 2, hlm., 80, April 2002. 
Indonesia. Dengan merujuk pada kenyataan demikian seakan menegasikan bahwa rekomendasi Ombudsman Republik Indonesia mempunyai kekuatan hukum mengikat (legally binding). Lantaran Kepala Daerah tidak memiliki kesadaran untuk patuh terhadap rekomendasi yang dikeluarkan oleh Ombudsman Republik Indonesia. Dengan demikian dapat dikatakan bahwa rekomendasi Ombudsman Republik Indonesia terkesan hanya sekedar saran biasa, yang jika dilaksanakan ataupun tidak dilaksanakan, tidak akan membawa pengaruh.

Ditambah tidak adanya daya paksa Ombudsman terhadap Penyelenggara Pelayanan Publik untuk melaksanakan rekomendasi yang dikeluarkan oleh Ombudsman Republik Indonesia Tentunya hal demikian mempunyai implikasi terhadap kualitas perlindungan hukum (kwaliteit van de rechtsbescherming), jaminan keadilan (rechtsvaardigheid) dan kepastian hukum (rechtszekerheid) untuk seluruh warga negara (Pelapor) atas penyelenggaraan pelayanan publik.

Berkenaan dengan jenis rekomendasi yang diimplementasikan, perlu diketahui bahwa jenis rekomendasi Ombudsman yang lazim dipraktikan berjumlah 4 (empat) jenis yakni: 1) rekomendasi yang disusun guna membantu penyelesaian masalah pelapor; 2) rekomendasi yang menyarankan pemberian sanksi guna pemberian dan efek jera; 3) rekomendasi yang diperuntukkan mencegah agar tidak terjadi tindakan maladministrasi dan 4) Rekomendasi untuk mengubah proses atau sistem yang mengakibatkan buruknya kualitas pelayanan umum. Keempat jenis Rekomendasi tersebut pada hakikatnya memiliki tujuan yang sama untuk mewujudkan tata kelola pemerintah yang baik (good governance). ${ }^{25}$ Dengan demikian rekomendasi Ombudsman Republik Indonesia berkaitan dengan tugasnya sebagai lembaga pengawas pelayanan publik yang dibentuk berdasarkan undang-undang untuk meningkatkan penyelenggaraan pemerintahan yang baik (good governance) serta menciptakan lingkungan yang

25 Dinny Wirawan Pratiwie, Urgensi Keberadaan Ombudsman Republik Indonesia Dalam Rangka Mewujudkan Good Governance (Ditinjau Dari Undang-Undang Nomor 37 Tahun 2008 Tentang Ombudsman Republik Indonesia), Jurnal Ilmiah Hukum, Volume 4, Nomor 1, hlm., 72, 2012. 
kondusif untuk pelayanan berupa hukum yang adil, termasuk pemberantasan dan mencegah perilaku Korupsi, Kolusi, dan Nepotisme. ${ }^{26}$

Berdasarkan hasil penelusuran tidak ditemukan praktiknya mengingat tingkat kepatuhan Kepala Daerah masih sangat rendah. Artinya tatkala Ombudsman Republik Indonesia mengeluarkan rekomendasi terhadap Kepala Daerah untuk memeriksa dan memberikan sanksi pelanggaran terhadap bawahannya tidak memberikan jaminan bahwa Kepala Daerah dengan sigap langsung melaksanakan rekomendasi Ombudsman Republik Indonesia dengan pertimbangannya sendiri.

Mudji Estiningsih mengemukakan bahwa tantangan Ombudsman dalam perwujudan negara hukum yang moderen dan demokratis di antaranya adalah kepatuhan pejabat publik dalam melaksanakan rekomendasi dari Ombudsman maupun merespon atau menanggapi surat-surat dari Ombudsman. ${ }^{27}$ Dengan demikian tantangan yang paling fundamental dari pelaksanaan fungsi rekomendasi Ombudsman Republik Indonesia adalah ketidakpatuhan Penyelenggara Pelayanan Publik khususnya Kepala Daerah terhadap rekomendasi yang dikeluarkan oleh Ombudsman Republik Indonesia. Dengan kata lain fungsi rekomendasi Ombudsman Republik Indonesia yang diatur dalam Undang-Undang Nomor 37 Tahun 2008 Tentang Ombudsman Republik Indonesia tidak berjalan efektif seakan tertidur (Slaapeende Regeling). Tentunya hal demikian mempunyai implikasi terhadap kualitas perlindungan hukum (kwaliteit van de rechtsbescherming), jaminan keadilan (rechtsvaardigheid) dan kepastian hukum (rechtszekerheid) untuk seluruh warga negara (Pelapor) atas penyelenggaraan pelayanan publik.

26 Nina Anggraeni, Ombudsman Republik Indonesia (Ori) Dan Pelayanan Publik (Studi Kasus Analisis Putusan Rekomendasi Ori Dan Efektivitas Rekomendasi Ori). Disusun Sebagai Salah Satu Syarat Menyelesaikan Program Studi strata II pada Jurusan Magister ilmu hukum Sekolah Pascasarjana Universitas Muhammadiyah Surakarta, 2018, hlm., 8.

27 Mudji Estiningsih, Fungsi Pengawasan Ombudsman Dalam Mewujudkan Pemerintahan Yang Baik (Studi Kasus Pemerintahan Daerah Istimewa Yogyakarta), Liberty, Yogyakarta, 2016, hlm., 129. 


\section{Bentuk dan Implementasi Sanksi yang Diberikan Kepada Kepala Daerah}

Dikarenakan Tidak Melaksanakan Rekomendasi Ombudsman Republik Indonesia

Terkait kewajiban Kepala Daerah untuk melaksanakan rekomendasi yang diberikan oleh Ombudsman sebagaimana disebutkan secara eksplisit dalam Pasal 351 ayat (4) Undang-Undang Nomor 23 Tahun 2014 tentang Pemerintahan Daerah Kepala daerah wajib melaksanakan rekomendasi Ombudsman sebagai tindak lanjut pengaduan masyarakat sebagaimana dimaksud pada ayat (1). Bahwa apabila Kepala Daerah tidak melaksanakan rekomendasi yang dikeluarkan oleh Ombudsman Republik Indonesia tentunya mempunyai konsekuensi atau akibat hukum (juridische gevolgen) berupa pengenaan sanksi administratif sebagaimana disebutkan dalam Pasal 351 ayat (5) Undang-Undang Nomor 23 Tahun 2014 Tentang Pemerintahan Daerah, sebagai berikut:

"Kepala daerah yang tidak melaksanakan rekomendasi Ombudsman sebagai tindak lanjut pengaduan masyarakat sebagaimana dimaksud pada ayat (4) diberikan sanksi berupa pembinaan khusus pendalaman bidang pemerintahan yang dilaksanakan oleh Kementerian serta tugas dan kewenangannya dilaksanakan oleh wakil kepala daerah atau pejabat yang ditunjuk"

Berdasarkan Pasal 36 ayat (1) Peraturan Pemerintah Nomor 12 Tahun 2017 Tentang Pembinaan Dan Pengawasan Penyelenggaran Pemerintahan daerah, Kepala daerah, wakil kepala daerah, anggota DPRD, dan daerah yang melakukan pelanggaran administratif dalam penyelenggaraan Pemerintahan Daerah dijatuhi sanksi administratif.

Terkait ketentuan pelanggaran administratif akibat tidak dilaksanakannya rekomendasi Ombudsman Republik Indonesia oleh Kepala Daerah disebutkan dalam Pasal 36 ayat (2) huruf r, bahwa kepala daerah tidak melaksanakan rekomendasi Ombudsman sebagai tindak lanjut pengaduan masyarakat atas:

1. penyelenggara Pemerintahan Daerah yang tidak melaksanakan kewajiban dan/ atau melanggar larangan sebagaimana dimaksud dalam ketentuan peraturan perundang-undangan mengenai pelayanan publik; dan 
2. pelaksana yang memberi pelayanan yang tidak sesuai dengan standar pelayanan sebagaimana dimaksud dalam ketentuan peraturan perundang-undangan mengenai pelayanan publik;

Kepala Daerah yang tidak melaksanakan Rekomendasi sebagaimana disebutkan Pasal 36 ayat 2 akan dijatuhi sanksi. Hal demikian dapat ditinjau dalam Pasal 46 Peraturan Pemerintah Nomor 12 Tahun 2017 Tentang Pembinaan Dan Pengawasan Penyelenggaran Pemerintahan daerah.

(1) Kepala daerah yang melakukan pelangaran administratif sebagaimana dimaksud dalam Pasal 36 ayat (2) huruf $r$ dijatuhi sanksi administratif berupa mengikuti program pembinaan khusus pendalaman bidang pemerintahan.

(2) Sanksi berupa mengikuti program pembinaan khusus pendalaman bidang pemerintahan sebagaimana dimaksud pada ayat (1) dijatuhkan oleh Menteri kepada gubernur serta oleh gubernur sebagai wakil Pemerintah Pusat kepada bupati/walikota.

(3) Penjatuhan sanksi sebagaimana dimaksud pada ayat (2) didasarkan atas hasil pemeriksaan secara teliti, objektif, dan didukung dengan data, informasi, dan/ atau dokumen lainnya yang berkaitan dengan dugaan pelangggaran dimaksud.

(5) Proses administratif penjatuhan sanksi scbagaimana dimaksud pada ayat (2) dilakukan oleh:

a. inspektorat jenderal Kementerian, untuk sanksi yang dijatuhkan oleh Menteri; dan

b. perangkat gubernur sebagai wakil Pemerintah Pusat, untuk sanksi yang dijatuhkan oleh gubernur sebagai wakil Pemerintah Pusat.

Adapun pasal yang telah disebutkan di atas, secara expressis verbis menyebutkan bahwa sanksi administrasi bagi Kepala Daerah yang tidak melaksanakan rekomendasi adalah mengikuti program pembinaan khusus pendalaman bidang pemerintahan. Hal selaras dikemukakan oleh Direktorat Jenderal Otonomi Daerah, Kementerian Dalam Negeri Republik Indonesia, Soni Sumarsono ${ }^{28}$, bahwa secara normatif memang tersedia mekanisme sanksi yang dapat diberikan terhadap Kepala Daerah jika tidak melaksanakan rekomendasi Ombudsman.

28 Hendra Friana, Mungkinkah Rekomendasi Ombudsman Berhentikan Anies Baswedan, https://tirto.id/mungkinkah-rekomendasi-ombudsman-berhentikan-anies-baswedan-cGPQ, diakses 27 Maret 2019. 
Berdasarkan Pasal 36 ayat (2) huruf r dijatuhi sanksi administratif berupa mengikuti program pembinaan khusus pendalaman bidang pemerintahan. Sebelum dijatuhi sanksi, Kementerian Dalam Negeri Republik Indonesia terlebih dulu melakukan verifikasi secara lebih teliti, objektif, dengan didukung data, informasi, dan dokumen lain demi memastikan adanya dugaan pelanggaran.

Pembinaan khusus adalah program yang mengirim Kepala Daerah yang melanggar aturan melaksanakan pendidikan dan latihan. Menurut Soni Sumarsono hal demikian dianggap perlu jika mereka dianggap tidak mengetahui penyelenggaraan pemerintahan daerah. ${ }^{29}$ Dengan demikian sanksi yang dapat diberikan oleh Kementerian Dalam Negeri Republik Indonesia terhadap Kepala Daerah yang tidak melaksanakan hanya terbatas pada pembinaan khusus.

Pada hakikatnya Ombudsman tidak memiliki kewenangan untuk memberikan sanksi administratif maupun sanksi pidana. Dalam hal ini sanksi dalam proses Ombudsman, khususnya terkait tidak dilaksanakannya rekomendasi, bukan berada di Ombudsman Republik Indonesia melainkan berada di penyelenggara pelayanan publik itu sendiri. Sebab itulah Ombudsman sering disebut sebagai magistrature of influence. Di samping itu ada faktor lain yang membuat rekomendasi Ombudsman Republik Indonesia efektif, yaitu kepemimpinan dan ketegasan dari lembaga penyelenggara pelayanan publik itu sendiri.

Akan tetapi pertanyaan muncul di benak masyarakat pada umumnya “apakah memang ada realisasi dari pelaksanaan pembinaan khusus terhadap Kepala Daerah yang tidak melaksanakan rekomendasi Ombudsman Republik Indonesia?". Berdasarkan penelitian yang dilakukan di beberapa kota melalui wawancara dengan beberapa Asisten Ombudsman Republik Indonesia tidak ditemukan peristiwa konkrit terkait realisasi pelaksanaan sanksi pembinaan khusus yang diberikan terhadap Kepala Daerah. Rekomendasi yang dikeluarkan oleh Ombudsman Republik Indonesia terkait pelaksanaan pembinaan khusus harus berhenti pada pejabat yang mempunyai kewenangan untuk memberikan

29 Id. 
sanksi pembinaan khusus. Dengan demikian di dalam praktiknya sanksi pembinaan khusus yang diberikan terhadap Kepala Daerah akibat tidak melaksanakan rekomendasi Ombudsman hanya merupakan bunyi ketentuan norma yang berlaku tidaklah implementatif, menggambarkan bahwa norma dari undang-undang tersebut tertidur (slaapende regeling).

Berdasarkan Pasal 351 ayat (5) Kepala daerah yang tidak melaksanakan rekomendasi Ombudsman sebagai tindak lanjut pengaduan masyarakat sebagaimana dimaksud pada ayat (4) diberikan sanksi berupa pembinaan khusus pendalaman bidang pemerintahan yang dilaksanakan oleh Kementerian serta tugas dan kewenangannya dilaksanakan oleh wakil kepala daerah atau pejabat yang ditunjuk.

Dengan mengacu redaksi pasal a quo Kepala Daerah sudah seyogianya mendapatkan sanksi pembinaan khusus pendalaman bidang pemerintahan yang dilaksanakan Inspektorat Jenderal Kementerian, untuk sanksi yang dijatuhkan oleh Menteri akibat tidak melaksanakan rekomendasi yang dikeluarkan oleh Ombudsman. Namun dalam realitas tidak ditemukan tindak lanjut dari rekomendasi penjatuhan sanksi terhadap atasan. Sebagai contoh Pertama, berdasarkan Rekomendasi Nomor: 0011/REK/0259.2010/BS-15/VII/2011 Tanggal 08 Juli 2011, dalam hal ini Walikota Bogor tidak mendapatkan sanksi pembinaan khusus yang dilakukan oleh Gubernur Jawa Barat. Kedua, berdasarkan Rekomendasi Nomor: 0001/REK/0692.2014/BS.38/I/2016 Tanggal 29 Januari 2016, dalam hal ini Gubernur tidak mendapatkan sanksi pembinaan khusus, bahkan Sudah dilaporkan kepada DPR RI dan Presiden RI: 1. Surat ORI Nomor:1042/ORISRT/IX/2016 Tanggal 14 September 2016 kepada Presiden RI; 2. Surat ORI Nomor: 1043/ORISRT/IX/2016 Tanggal 14 September 2016 kepada Ketua DPR RI. Ketiga, berdasarkan Rekomendasi Nomor: 0001/REK/0246.2013/I/2017 Tanggal 01 Februari 2017, dalam hal ini Walikota Yogyakarta tidak mendapatkan sanksi pembinaan khusus.

Jika dicermati makna dari frasa "Atasan" yang disebutkan dalam pasal $a$ quo mempunyai makna yang subyektif. Kendati dalam sistem Tata Negara atau Lembaga Negara Presiden dan Dewan Perwakilan Rakyat merupakan Lembaga 
Tinggi Negara yang menaungi pemerintahan yang ada di bawahnya, namun bukan berarti menjadikan lembaga tersebut atasan langsung instansi yang bersangkutan. Alasan lainya adalah mengacu pada proses pemilihan Presiden, DPR/DPD RI Gubernur maupun Bupati/Walikota, semuanya melalui proses pemilihan umum secara langsung dimana masyarakat menentukan pilihannya. Dengan demikian masing-masing mempunyai basis pengaruh politik atau legitimasi tanpa adanya intervensi dari pihak lain. Maka dari itu dalam kasus di atas Menteri Dalam Negeri tidak langsung menanggapi rekomendasi dengan pemberian sanksi administratif terhadap Kepala Daerah, sebab harus melewati pertimbangan-pertimbangan hukum dan politik.

Realitas tersebut menguatkan argumentasi bahwa Ombudsman Republik Indonesia tidak mempunyai daya paksa terhadap Kepala Daerah untuk mematuhi dan melaksanakan rekomendasi yang dikeluarkan oleh Ombudsman Republik Indonesia sebagaimana merujuk konstruksi Pasal 38 ayat (4) UU Ombudsman yang menyebutkan bahwa dalam hal Terlapor dan atasan Terlapor tidak melaksanakan Rekomendasi atau hanya melaksanakan sebagian Rekomendasi dengan alasan yang tidak dapat diterima oleh Ombudsman, Ombudsman dapat mempublikasikan atasan Terlapor yang tidak melaksanakan Rekomendasi dan menyampaikan laporan kepada Dewan Perwakilan Rakyat dan Presiden.

Selain itu Pasal 46 ayat (1) Peraturan Pemerintah Nomor 12 Tahun 2017 Tentang Pembinaan dan Pengawasan Penyelenggaran Pemerintahan Daerah menyebutkan bahwa Kepala daerah yang melakukan pelangaran administratif sebagaimana dimaksud dalam Pasal 36 ayat (2) huruf $r$ dijatuhi sanksi administratif berupa mengikuti program pembinaan khusus pendalaman bidang pemerintahan. Dengan demikian mempertegas bahwa Ombudsman Republik Indonesia hanya memiliki kewenangan yang limitatif dalam mengupayakan mewujudkan efektivitas penyelenggaraan pelayanan publik. ${ }^{30} \mathrm{Hal}$ demikian pula yang menjadi perhatian utama tatkala Ombudsman Republik Indonesia sudah melakukan tugas dan fungsinya namun pada akhirnya upaya tersebut akan

30 Adam Setiawan, Peran Ombudsman Dalam Mengawal Pelayanan Publik, Harian Bhirawa, 18 April 2019. 
dimentahkan begitu saja oleh terlapor atau atasan terlapor maka akan menjadi sia-sia upaya Ombudsman Republik Indonesia, dikarenakan tingkat kesadaran hukum dari Terlapor atau Atasan Terlapor masih sangat rendah mengakibatkan Ombudsman Republik Indonesia seperti tidak mempunyai kekuatan untuk memaksakan pelaksanaan rekomendasi. Dengan tidak adanya daya paksa Ombudsman Republik Indonesia terhadap Kepala Daerah untuk mematuhi rekomendasi tentunya mempunyai implikasi terhadap kualitas perlindungan hukum (kwaliteit van de rechtsbescherming), jaminan keadilan (rechtsvaardigheid) dan kepastian hukum (rechtszekerheid) untuk seluruh warga negara (Pelapor) atas penyelenggaraan pelayanan publik.

Berdasarkan pemaparan di atas dapat dijelaskan bahwa ada beberapa faktor yang mengakibatkan pemberian sanksi terhadap kepala daerah yang tidak melaksanakan Rekomendasi Ombudsman Republik Indonesia menjadi tidak efektif sebagai berikut:

1. Faktor Substansi;

Pengaturan mengenai pemberian sanksi pembinaan khusus terhadap Kepala Daerah yang tidak melaksanakan rekomendasi sekarang dirasa tidaklah efektif. Sebab pada tahap implementasi telah membuka ruang bagi pemberi sanksi dengan pertimbangan subjektif untuk mengabaikan rekomendasi Ombudsman dalam penjatuhan sanksi untuk tidak memberikan sanksi terhadap Terlapor. Sudah seyogianya diatur secara detail dan ditegaskan frasa "wajib" dalam undang-undang bahwa bagi Kepala Daerah yang tidak melaksanakan rekomendasi wajib melaksanakan sanksi pembinaan khusus.

2. Faktor Struktur

Pertama, Kepala Daerah sebagai Terlapor atau Atasan Terlapor yang notabene merupakan pembina pelayanan publik di daerah masih ada yang tidak mematuhi rekomendasi yang dikeluarkan oleh Ombudsman Republik Indonesia. Kedua, Menteri Dalam Negeri yang tidak melaksanakan rekomendasi Ombudsman dalam penjatuhan sanksi. 
3. Faktor budaya

Masih kentalnya kebiasaan patologis dalam penyelenggaraan pelayanan publik sehingga tidak heran masih ada Kepala Daerah yang tidak mematuhi rekomendasi yang diberikan oleh Ombudsman Republik Indonesia.

\section{Penutup}

Fungsi rekomendasi Ombudsman Republik Indonesia yang diberikan terhadap Kepala Daerah adalah sebagai saran atau nasihat yang harus dilakukan guna memperbaiki kualitas pelayanan yang dikeluhkan masyarakat khususnya yang ada di daerah. Rekomendasi yang dikeluarkan oleh Ombudsman Republik Indonesia belum efektif. Secara substansi Undang-Undang Nomor 37 Tahun 2008 Tentang Ombudsman Republik Indonesia, Undang-Undang Nomor 25 Tahun 2009 Tentang Pelayanan Publik dan Undang-Undang Nomor 23 Tahun 2014 Tentang Pemerintahan Daerah, Rekomendasi Ombudsman mempunyai kekuatan hukum mengikat (legally binding) sehingga wajib untuk dilaksanakan. Namun pada tahap implementasinya masih ada rekomendasi yang tidak dilaksanakan oleh Kepala Daerah. Hal demikian dipengaruhi kesadaran hukum yang masih rendah untuk mematuhi rekomendasi Ombudsman Republik Indonesia. Sehingga tidak menutup kemungkinan pelaksanaannya hanya bergantung pada upaya persuasif. Jenis rekomendasi yang lazim diberikan oleh Ombudsman Republik Indonesia terhadap Kepala Daerah (a) Membantu menyelesaikan masalah; (b) Rekomendasi pemberian sanksi; (c) Mencegah maladministrasi; dan (d) Mengubah proses atau sistem.

Implementasi sanksi yang diberikan terhadap Kepala Daerah dikarenakan tidak melaksanakan Rekomendasi Ombudsman Republik Indonesia. Secara eksplisit disebutkan dalam Undang-Undang Nomor 23 Tahun 2014 Tentang Pemerintahan Daerah bahwa Kepala Daerah yang tidak melaksanakan rekomendasi Ombudsman Republik Indonesia akan mendapatkan sanksi pembinaan khusus yang diberikan oleh Kementerian Dalam Negeri. Sanksi Pembinaan khusus adalah program yang mengirim Kepala Daerah yang melanggar aturan melaksanakan pendidikan dan latihan. Berdasarkan hasil penelusuran 
tidak ditemukan peristiwa konkrit dari implementasi sanksi pembinaan khusus. Karena beberapa rekomendasi penjatuhan sanksi yang diberikan oleh Ombudsman Republik Indonesia seringkali diabaikan begitu saja oleh Menteri Dalam Negeri dan Kepala Daerah dengan harus melewati pertimbanganpertimbangan hukum dan politik.

\section{Daftar Pustaka}

\section{Buku:}

Amiruddin dan Zainal Asikin, Pengantar Metode Penelitian Hukum, Raja Grafindo, Jakarta, 2004,

C.F.G. Sunaryati Hartono et.al., Panduan Investigasi untuk Indonesia, The Asia Foundation Indonesia, Jakarta 2003. ed., Peranan Ombudsman Dalam Rangka Pemberantasan Dan

Pencegahan Korupsi Serta Penyelenggaraan Pemerintahan Yang Bersih, Jakarta, Komisi Ombudsman Nasional, 2005.

Mudji Estiningsih, Fungsi Pengawasan Ombudsman Dalam Mewujudkan Pemerintahan Yang Baik (Studi Kasus Pemerintahan Daerah Istimewa Yogyakarta), Liberty, Yogyakarta, 2016.

Nina Pane, Adnan Buyung Nasution: Nasihat Untuk SBY, Kompas, Jakarta, 2012,

Sudikno Mertokusumo, Mengenal Hukum Suatu Pengantar, Liberty, Yogyakarta, 2008.

\section{Jurnal:}

Abi Ma'ruf Radjab, Kekuatan Mengikat Putusan Ajudikasi Ombudsman dalam Proses Penyelesaian Sengketa Pelayanan Publik", Jurnal Veritas et Justitia, No.2 Volume 1, Nomor 2, Desember 2015.

Dinny Wirawan Pratiwie, Urgensi Keberadaan Ombudsman Republik Indonesia Dalam Rangka Mewujudkan Good Governance (Ditinjau Dari UndangUndang Nomor 37 Tahun 2008 Tentang Ombudsman Republik Indonesia), Jurnal Ilmiah Hukum, Volume 4, Nomor 1, 2012.

Galang Asmara, Peranan Ombudsman Dalam Mewujudkan Good Governance di Indonesia, Jurnal Perspektif, Volume VII Nomor 2, April 2002 
Mary A. Marshall dan Linda C. Reif, The Ombudsman: Maladministration and Alternative Dispute, Alberta Law Review, Volume XXXIV Nomor I Tahun 1995.

Muhamad Rus'anYasin, Telaah Tentang Rekomendasi Ombudsman Terhadap Fraud Perbankan, Jurnal Katalogis, Volume 4, Nomor 11, November 2016.

Nina Anggraeni, "Ombudsman Republik Indonesia (Ori) Dan Pelayanan Publik (Studi Kasus Analisis Putusan Rekomendasi Ori Dan Efektivitas Rekomendasi Ori)". Disusun Sebagai Salah Satu Syarat Menyelesaikan Program Studi strata II pada Jurusan Magister ilmu hukum Sekolah Pascasarjana Universitas Muhammadiyah Surakarta, 2018.

\section{Koran dan Berita Online:}

Adam Setiawan, Peran Ombudsman Dalam Mengawal Pelayanan Publik", Harian Bhirawa, (dimuat 18 April 2019).

Detiknews, Ombudsman: Kasus GKI Yasmin Jadi Preseden Buruk Penegakan Hukum https://news.detik.com/berita/d-1791550/ombudsman-kasusgki-yasmin-jadi-preseden-buruk-penegakan-hukum, diakses 25 Juni 2020

DetikNews, Ombudsman akan Tegur Ahok karena Tak Jalankan Rekomendasi https://news.detik.com/berita-jawa-barat/d-3330136/ombudsman-rikeluhan-buruknya-layanan-pemda-paling-tinggi, diakses 1 April 2020.

Tirto Id, "Mungkinkah Rekomendasi Ombudsman Berhentikan Anies Baswedan"https://tirto.id/mungkinkah-rekomendasi-ombudsmanberhentikan-anies-baswedan-cGPQ, diakses 27 Maret 2018.

\section{Peraturan Perundang-undangan:}

Undang-Undang Dasar Negara Republik Indonesia 1945

Undang-Undang Republik Indonesia Nomor 37 Tahun 2008 Tentang Ombudsman Republik Indonesia, Lembaran Negara Republik Indonesia Tahun 2008 Nomor 139, Tambahan Lembaran Negara Republik Indonesia Nomor 4899

Undang-Undang Nomor 25 Tahun 2009 Tentang Pelayanan Publik Lembaran Negara Republik Indonesia Tahun 2009 Nomor 112, Tambahan Lembaran Negara Republik Indonesia Nomor 5038.

Undang-Undang Nomor 12 Tahun 2011 tentang Pembentukan Peraturan Peraturan Perundang-Undangan, Lembaran Negara Republik Indonesia Tahun 2011 Nomor 82, Tambahan Lembaran Negara Republik Indonesia Nomor 5234.

Undang-Undang Nomor 23 Tahun 2014 Tentang Pemerintahan Daerah Lembaran Negara Republik Indonesia Tahun 2014 Nomor 244, Tambahan Lembaran Negara Republik Indonesia Nomor 5587. 